\title{
The content of cadmium, cobalt and nickel in laryngeal carcinoma
}

Janusz Klatka', Marek Remer², Ryszard Dobrowolski , Wioletta Pietruszewska, Agnieszka Trojanowska ${ }^{5}$, Henryk Siwiec ${ }^{1}$, Małgorzata Charytanowicz ${ }^{6}$

\author{
${ }^{1}$ Chair and Department of Otolaryngology, Medical University, Lublin, Poland \\ 2Department of Otolaryngology, District Hospital, Zamosc, Poland \\ ${ }^{3}$ Department of Analytic Chemistry and Instrumental Analysis, Maria Curie Sklodowska \\ University, Lublin, Poland \\ ${ }^{4}$ Chair and Department of Otolaryngology, Medical University, Lodz, Poland \\ ${ }^{5}$ Department of Radiology, Medical University, Lublin, Poland \\ 6 Institute of Mathematics and Computer Science, The John Paul II Catholic University, \\ Lublin, Poland
}

Submitted: 26 January 2010
Accepted: 14 March 2010

Arch Med Sci 2011; 7, 3: 517-522

DOI: 10.5114/aoms.2011.23422

Copyright (c) 2011 Termedia \& Banach

\begin{abstract}
Introduction: The aim of the study was to determine the content of cadmium $(\mathrm{Cd})$, cobalt $(\mathrm{Co})$ and nickel $(\mathrm{Ni})$ in the samples from laryngeal carcinoma in comparison with the level of these elements in the samples of healthy mucous membrane from the same larynx.

Material and methods: The study was conducted on 43 patients with laryngeal carcinoma. The levels of $\mathrm{Cd}, \mathrm{Co}$, and $\mathrm{Ni}$ in carcinoma and healthy control tissues was determined by inductively coupled plasma optical emission spectrometry (ICP - OES) using sequential spectrometer.

Results: No significant differences were found between the levels of the $\mathrm{Cd}, \mathrm{Co}$, and $\mathrm{Ni}$ in laryngeal carcinoma vs tissues without carcinoma. However, it was noted that the concentration of $\mathrm{Cd}$ in tumors of patients with metastases to cervical lymph nodes was significantly higher than in tumors without metastases. The content of Co was significantly higher in more advanced laryngeal tumors: in stage-T4 than in stage T3. It is of interest that the levels of $\mathrm{Cd}, \mathrm{Co}$ and $\mathrm{Ni}$ were significantly higher in tumors in patients from rural than urban areas.

Conclusions: The imbalance in the level of nickel, cadmium and cobalt in laryngeal cancer may be due to a changed cellular metabolism in the cancer process. However, the results of our study reveal the significant differences in the concentration of these metals between patients from urban and rural areas which suggests that this fact may be related to environmental or occupational factors and therefore it requires further study.
\end{abstract}

Key words: cadmium, cobalt, nickel, trace elements, laryngeal carcinoma.

\section{Introduction}

Recently undertaken studies in the field of metal carcinogenesis suggest that epigenetic mechanisms may play a role in metal-induced carcinogenesis. Exposure to carcinogenic metals such as nickel (Ni) and cadmium (Cd) can perturb DNA methylation levels as well as global and gene-specific histone tail posttranslational modification marks [1]. The authors suggest that gene expression can be regulated by both genetic

\author{
Correspondence author: \\ Prof. Janusz Klatka \\ Department of \\ Otolaryngology, \\ Medical University \\ 8 Jaczewskiego \\ 20-090 Lublin, Poland \\ E-mail: janusz.klatka@wp.pl
}


and epigenetic mechanisms and therefore both of them must be considered when studying the mechanism underlying the toxicity and cell transforming ability of carcinogenic metals and other toxicants, as well as aberrant changes in gene expression that occur in diseases such as cancer. It was reported that carcinogenic nickel compounds decreased global histone $\mathrm{H} 4$ acetylation. Nickel ions increase histone $\mathrm{H} 3$ lysine 9 dimethylation and induce transgene silencing [2]. Nickel ions induce transgene silencing by increasing histone H3K9 dimethylation, and this effect is mediated by the inhibition of $\mathrm{H} 3 \mathrm{~K} 9$ demethylation. There is no doubt that cadmium $(\mathrm{Cd})$ is a human carcinogen that likely acts via epigenetic mechanisms. Cadmium (Cd) is an effective inhibitor of DNA methyltransferase (MeTase) and initially induces DNA hypomethylation, but prolonged exposure results in DNA hypermethylation and enhanced DNA MeTase activity [3]. On the other hand, cobalt (Co) is an essential trace element as a constituent of vitamin $B_{12}$ (cyanocobalamin) and its deficiency results in anaemia. However, different compounds of Co are also described as highly toxic and/or radiotoxic for individuals or the environment. The underlying mechanism of cobalt toxicity is not clearly established. According to Gault et al., the toxicity of $\mathrm{Co}(\mathrm{II})$ and of irradiation arises from production of reactive oxygen species [4].

Studies on the relationship between trace metals and carcinoma of the larynx are few, desultory and inconclusive. This study is focused mainly on the determination of the levels of cadmium (Cd), cobalt (Co) and nickel (Ni) in laryngeal tissues, taking into account the metrological evaluation aspect. For this reason certified reference materials (CRM) were applied for validation of the analytical procedure.

The aim of this study was to evaluate the concentration of cadmium (Cd), cobalt (Co) and nickel $(\mathrm{Ni})$ in laryngeal tissues with and without cancer. We wanted to find out if the content of the studied elements in the tumour is related to its size, and presence of metastasis to lymph nodes and if there is any relationship between the level of studied metals in carcinoma tissue and the environment where the patients live.

\section{Material and methods}

The study was conducted on 43 samples obtained from squamous cell laryngeal carcinoma and 43 corresponding cancer-free laryngeal tissues from the same male patients age 44 to 76 years (average age 62 years) after total laryngectomy. The patients were treated in the Department of Otolaryngology at the Medical University of Lublin. Patients who were taking microelements as supplements to their diet were excluded from the study. The analysed group included 29 patients
(67.4\%) with advanced carcinoma according to the TNM cancer classification [5], described as stage $\mathrm{T} 3$, and 14 patients (32.6\%) with a stage T4 tumour. Neck lymph node metastases were observed in 27 patients (62.8\%). The condition of lymph nodes marked N1 was found in 22 patients (51.2\%), N2 in 4 patients (9.3\%), N3 in 1 patient $(2.3 \%)$. All the patients in the study group were tobacco smokers, 26 patients (60.5\%) were heavy drinkers and the remaining 17 patients (39.5\%) drank occasionally. In this group 24 patients (55.8\%) came from urban areas and 19 patients (44.2\%) from rural areas.

\section{Experimental}

Samples of laryngeal tissues were weighed (about $0.5 \pm 0.001 \mathrm{~g}$ ) and digested by $3 \mathrm{ml}$ of Suprapur nitric acid (Merck, Germany) using the closed mineralization system Mars 5 (CEM, USA). Mineralization parameters were as follows: end temperature $195^{\circ} \mathrm{C}$, pressure 260 psi, time of mineralization $8 \mathrm{~min}$. After the mineralization the residue was transferred to polyethylene volumetric flasks $(25 \mathrm{ml})$ and filled up with bidistilled water. The total content of the elements was determined by inductively coupled plasma optical emission spectrometry (ICP-OES) using a sequential spectrometer, model Liberty II AX (Varian, Australia). The content of $\mathrm{Cd}, \mathrm{Ni}$, and $\mathrm{Co}$ in the studied material was calculated on dry tissues. In order to introduce a calculation factor another part of laryngeal tissues was dried to a solid mass using a laboratory dryer, model SML 35/250 (Zelmet, Poland) at $105^{\circ} \mathrm{C}$. The applied analytical procedure was validated using certified reference materials: bovine muscle BCR 184 and bovine liver NCS ZC $85050(T)$. The obtained results - the content of studied elements in CRM - were in good agreement with certified values.

The results of determinations were analysed statistically with the program Statistica ver. 6.1. The comparison of the levels of concentration of particular elements was carried out using the Mann-Whitney test of significance.

\section{Results}

The average content of cadmium in the samples from laryngeal carcinoma was $0.449 \mathrm{mg} / \mathrm{kg}$ of dry mass (Table I). The average concentration of this element in healthy tissue was $0.227 \mathrm{mg} / \mathrm{kg}$. The statistical analysis did not reveal any significant differences in the concentration of cadmium in laryngeal carcinoma and in healthy tissue ( $p=0.214 ; p>0.05$ ). Nor was there found a statistically significant relationship between the concentration of cadmium in the laryngeal carcinoma and T stage $(p>0.05)$ (Table II). The 
studies of concentration of cadmium revealed a statistically significantly higher concentration of cadmium in laryngeal carcinoma in patients from rural areas than in patients from urban areas $(p=0.028 ; p<0.05)$ (Table III). The average concentration of cadmium in laryngeal carcinoma in patients from rural areas was $0.484 \mathrm{mg} / \mathrm{kg}$ while the average concentration in laryngeal carcinoma in patients from urban areas was $0.422 \mathrm{mg} / \mathrm{kg}$. The studies performed to find out the concentration of cadmium revealed a statistically significant relationship ( $p=0.036 ; p<0.05$ ) between the content of this element in laryngeal carcinoma and the condition of lymph nodes represented by the $\mathrm{N}$ stage (Table IV). The average concentration of cadmium in laryngeal carcinoma with the stage

Table I. Comparison of the concentration of Cd, Co, Ni in laryngeal carcinomas with the concentration of these metals in healthy mucous membrane of larynx in controls

\begin{tabular}{|lccccc|}
\hline \multirow{2}{*}{ Metals } & \multicolumn{2}{c}{ Control $(n=43)$} & \multicolumn{2}{c|}{ Cancer $(n=43)$} & Value of $p^{\mathrm{a}}$ \\
\cline { 2 - 6 } & $\begin{array}{c}\text { Mean } \pm \text { SD } \\
{[\mathrm{mg} / \mathrm{kg} \text { dry mass }]}\end{array}$ & $\begin{array}{c}\text { Median } \\
{[\mathrm{mg} / \mathrm{kg} \text { dry mass }]}\end{array}$ & $\begin{array}{c}\text { Mean } \pm \text { SD } \\
{[\mathrm{mg} / \mathrm{kg} \text { dry mass }]}\end{array}$ & $\begin{array}{c}\text { Median } \\
{[\mathrm{mg} / \mathrm{kg} \text { dry mass }]}\end{array}$ \\
\hline $\mathrm{Cd}$ & $0.227 \pm 0.293$ & 0.121 & $0.449 \pm 0.529$ & 0.265 & 0.214 (NS) \\
\hline $\mathrm{Co}$ & $0.017 \pm 0.013$ & 0.015 & $0.031 \pm 0.0375$ & 0.015 & 0.117 (NS) \\
\hline $\mathrm{Ni}$ & $0.057 \pm 0.080$ & 0.030 & $0.131 \pm 0.214$ & 0.030 & 0.060 (NS) \\
\hline
\end{tabular}

aMann-Whitney's tests, NS - non significant

Table II. Comparison of the concentration of Cd, Co, Ni in T3 degree advanced tumor in laryngeal carcinomas with the concentration of these metals in T4 degree advanced tumor in laryngeal carcinomas

\begin{tabular}{|lccccc|}
\hline Metals & \multicolumn{2}{c}{ Tumor T3 $(n=29)$} & Tumor T4 $(n=14)$ & Value of $p^{\text {a }}$ \\
\cline { 2 - 5 } & $\begin{array}{c}\text { Mean } \pm \text { SD } \\
{[\mathrm{mg} / \mathrm{kg} \text { dry mass }]}\end{array}$ & $\begin{array}{c}\text { Median } \\
{[\mathrm{mg} / \mathrm{kg} \text { dry mass }]}\end{array}$ & $\begin{array}{c}\text { Mean } \pm \text { SD } \\
{[\mathrm{mg} / \mathrm{kg} \text { dry mass }]}\end{array}$ & $\begin{array}{c}\text { Median } \\
{[\mathrm{mg} / \mathrm{kg} \text { dry mass }]}\end{array}$ \\
\hline Cd & $0.404 \pm 0.552$ & 0.192 & $0.544 \pm 0.484$ & 0.522 & $0.166(\mathrm{NS})$ \\
\hline $\mathrm{Co}$ & $0.025 \pm 0.034$ & 0.015 & $0.044 \pm 0.043$ & 0.015 & 0.033 \\
& & & & $0.05)$ \\
\hline $\mathrm{Ni}$ & $0.104 \pm 0.217$ & 0.030 & $0.185 \pm 0.202$ & 0.063 & $0.190(\mathrm{NS})$ \\
\hline
\end{tabular}

aMann-Whitney's tests, NS - non significant

Table III. Comparison of the concentration of $\mathrm{Cd}, \mathrm{Co}$, Ni in laryngeal carcinomas in patients from urban regions with the concentration of these metals in laryngeal carcinomas in patients from rural regions

\begin{tabular}{|c|c|c|c|c|c|}
\hline \multirow[t]{2}{*}{ Metals } & \multicolumn{2}{|c|}{ Patients from rural regions $(n=19)$} & \multicolumn{2}{|c|}{ Patients from urban regions $(n=24)$} & \multirow[t]{2}{*}{ Value of $p^{a}$} \\
\hline & $\begin{array}{c}\text { Mean } \pm \text { SD } \\
{[\mathrm{mg} / \mathrm{kg} \text { dry mass }]}\end{array}$ & $\begin{array}{c}\text { Median } \\
{[\mathrm{mg} / \mathrm{kg} \text { dry mass }]}\end{array}$ & $\begin{array}{c}\text { Mean } \pm \text { SD } \\
{[\mathrm{mg} / \mathrm{kg} \text { dry mass }]}\end{array}$ & $\begin{array}{c}\text { Median } \\
{[\mathrm{mg} / \mathrm{kg} \text { dry mass }]}\end{array}$ & \\
\hline $\mathrm{Cd}$ & $0.484 \pm 0.227$ & 0.508 & $0.422 \pm 0.685$ & 0.045 & $\begin{array}{c}0.028 \\
(p<0.05)\end{array}$ \\
\hline Co & $0.046 \pm 0.050$ & 0.015 & $0.019 \pm 0.017$ & 0.015 & $\begin{array}{c}0.007 \\
(p<0.05)\end{array}$ \\
\hline $\mathrm{Ni}$ & $0.210 \pm 0.277$ & 0.070 & $0.068 \pm 0.118$ & 0.030 & $\begin{array}{c}0.005 \\
(p<0.05)\end{array}$ \\
\hline
\end{tabular}

aMann-Whitney's tests, NS - non significant

Table IV. Comparison of the concentration of $\mathrm{Cd}, \mathrm{Co}$, Ni in laryngeal carcinomas in patients with metastasis ( $\mathrm{N}+)$ to lymph nodes in the neck with the concentration of these metals in laryngeal carcinomas in patients without ( $\mathrm{N}-$ ) metastasis to lymph nodes

\begin{tabular}{|c|c|c|c|c|c|}
\hline \multirow[t]{2}{*}{ Metals } & \multicolumn{2}{|c|}{$\mathrm{N}+(n=27)$} & \multicolumn{2}{|c|}{$\mathrm{N}-(n=16)$} & \multirow[t]{2}{*}{ Value of $p^{a}$} \\
\hline & $\begin{array}{c}\text { Mean } \pm \text { SD } \\
{[\mathrm{mg} / \mathrm{kg} \text { dry mass }]}\end{array}$ & $\begin{array}{c}\text { Median } \\
{[\mathrm{mg} / \mathrm{kg} \text { dry mass }]}\end{array}$ & $\begin{array}{c}\text { Mean } \pm \text { SD } \\
{[\mathrm{mg} / \mathrm{kg} \text { dry mass }]}\end{array}$ & $\begin{array}{c}\text { Median } \\
{[\mathrm{mg} / \mathrm{kg} \text { dry mass }]}\end{array}$ & \\
\hline$C d$ & $0.693 \pm 0.664$ & 0.513 & $0.305 \pm 0.375$ & 0.072 & $\begin{array}{c}0.036 \\
(p<0.05)\end{array}$ \\
\hline Co & $0.031 \pm 0.034$ & 0.015 & $0.030 \pm 0.044$ & 0.015 & 0.611 (NS) \\
\hline $\mathrm{Ni}$ & $0.095 \pm 0.136$ & 0.030 & $0.190 \pm 0.299$ & 0.030 & 0.233 (NS) \\
\hline
\end{tabular}

aMann-Whitney's tests, NS - non significant 
Table V. Comparison of the concentration of $\mathrm{Cd}$, Co, Ni in healthy laryngeal mucous membrane in patients from urban regions with the concentration of these metals in healthy laryngeal mucous membrane in patients from rural regions

\begin{tabular}{|lccccc|}
\hline Metals & \multicolumn{2}{c}{ Patients from rural regions $(n=19)$} & \multicolumn{2}{c|}{ Patients from urban regions $(n=24)$} & \multirow{2}{*}{ Value of $p^{\mathrm{a}}$} \\
\cline { 2 - 5 } & $\begin{array}{c}\text { Mean } \pm \text { SD } \\
{[\mathrm{mg} / \mathrm{kg} \text { dry mass }]}\end{array}$ & $\begin{array}{c}\text { Median } \\
{[\mathrm{mg} / \mathrm{kg} \text { dry mass }]}\end{array}$ & $\begin{array}{c}\text { Mean } \pm \text { SD } \\
{[\mathrm{mg} / \mathrm{kg} \text { dry mass }]}\end{array}$ & $\begin{array}{c}\text { Median } \\
{[\mathrm{mg} / \mathrm{kg} \text { dry mass }]}\end{array}$ \\
\hline Cd & $0.189 \pm 0.117$ & 0.182 & $0.257 \pm 0.380$ & 0.072 & 0.139 (NS) \\
\hline Co & $0.020 \pm 0.017$ & 0.015 & $0.016 \pm 0.009$ & 0.015 & 0.428 (NS) \\
\hline $\mathrm{Ni}$ & $0.089 \pm 0.107$ & 0.030 & $0.032 \pm 0.034$ & 0.030 & $\begin{array}{c}0.002 \\
(p<0.005)\end{array}$ \\
\end{tabular}

aMann-Whitney's tests, NS - non significant

$\mathrm{N}(-)$ was $0.305 \mathrm{mg} / \mathrm{kg}$, while in laryngeal carcinoma with the stage $\mathrm{N}(+)$ it was $0.692 \mathrm{mg} / \mathrm{kg}$.

The average content of cobalt in the samples from laryngeal carcinoma was $0.031 \mathrm{mg} / \mathrm{kg}$ of dry mass (Table I) while the average concentration of this element in the healthy tissue was $0.017 \mathrm{mg} / \mathrm{kg}$. The statistical analysis did not reveal any significant differences in the concentration of cobalt in carcinoma tissue and in healthy tissue $(p=0.117$; $p>0.05$ ). There was a statistically significantly higher concentration of cobalt in more advanced laryngeal tumours (T4) in comparison with less advanced tumours (T3) (Table II). There was no statistically significant relationship between the concentration of cobalt in tissue infiltrated by carcinoma and the $\mathrm{N}$ stage $(p>0.05)$ (Table IV). In the studies that were carried out it was found that the concentration of cobalt was statistically significantly higher in laryngeal carcinoma in patients from rural areas than in laryngeal carcinoma in patients from urban areas $(p=0.033$; $p<0.05)$. The mean content of cobalt in laryngeal carcinoma in patients from rural areas was $0.046 \mathrm{mg} / \mathrm{kg}$ while the mean concentration in laryngeal carcinoma in patients from urban areas was $0.019 \mathrm{mg} / \mathrm{kg}$ (Table III).

In this study the average content of nickel in the samples from laryngeal carcinoma was $0.131 \mathrm{mg} / \mathrm{kg}$ of dry mass (Table II). The mean concentration of this element in the healthy tissue was $0.057 \mathrm{mg} / \mathrm{kg}$. The statistical analysis revealed no significant differences in the concentration of nickel in carcinoma tissue and in healthy tissue ( $p=0.060$; $p>0.05)$. We have not found any statistically significant relationship between the concentration of nickel in carcinoma and the size of tumour (T stage $(p>0.05)$ ) (Table II). There was no statistically significant relationship between the concentration of nickel in the tissue infiltrated by carcinoma and the presence of metastases to lymph nodes ( $\mathrm{N}$ stage) ( $p>0.05)$ (Table IV). However, the studies revealed a statistically significantly higher concentration of nickel in laryngeal carcinoma in patients from rural areas in comparison with its concentration in laryngeal carcinoma in patients from urban areas $(p=0.007$; $p<0.05)$. The mean concentration of nickel in laryngeal carcinoma in patients from rural areas was $0.209 \mathrm{mg} / \mathrm{kg}$ while the mean concentration in laryngeal carcinoma in patients from urban areas was $0.067 \mathrm{mg} / \mathrm{kg}$ (Table III). It was also observed that the concentration of nickel in samples of tissues without cancer from the patients from rural areas was significantly higher in comparison with the nickel content in the healthy tissue from the patients from urban areas (Table V).

\section{Discussion}

Cadmium is a widespread toxic and carcinogenic metal $[6,7]$. In occupational studies, cadmium exposure has been associated with increased cancer mortality, including lung, prostate and renal cancer [8-11]. Population-based studies conducted in heavily polluted areas have linked cadmium to an increased risk of cancer $[12,13]$.

Nickel is a potent carcinogen in experimental animals, and epidemiological studies among workers in certain nickel industries suggest a connection between nickel exposure and tumours in the respiratory tract $[14,15]$.

The mechanism of cobalt-induced carcinogenesis is not clearly explained. Exposure to cobalt sulfate by inhalation resulted in increased incidence of alveolar/bronchiolar neoplasms and a spectrum of inflammatory, fibrotic, and proliferative lesions in the respiratory tracts of male and female rats and mice [16]. Several cobalt compounds have induced sarcomas at injection sites in animals [17].

Our results indicated that mean concentrations of cobalt, nickel and cadmium in carcinoma of the larynx compared with cancer-free larynx tissues were higher but these differences were not significant. In the tumours in patients with metastases to lymph nodes in the cervical region statistically significantly higher concentration of cadmium was observed compared with tumours in patient $\mathrm{s}$ with no metastatic changes in the regional lymph nodes. The results of our studies may suggest that a high concentration of cadmium in 
laryngeal carcinoma may create favourable conditions for the development of metastases. Apart from that a significantly higher concentration of cobalt in more advanced tumours (T4) in comparison with the less advanced tumours may indicate the participation of this metal in the stimulation of the proliferation processes in laryngeal carcinoma.

Data from our studies revealed a significantly higher concentration of nickel, cobalt and cadmium in tumours in patients from rural areas in comparison with the concentration of these metals in tumours in patients from urban areas. Significantly elevated levels of cadmium and nickel were found in the study carried out by RostowskaNadolska and Pośpiech [18]. Unlike our results a significant increase in cadmium in laryngeal carcinoma was reported in the study by Pilch et al. [19]. Contrary to our studies an increased level of cobalt in laryngeal carcinoma in comparison with the healthy tissue was reported in the studies by Rostowska-Nadolska and Pośpiech [18] and Collecchi et al. [20].

Levels of trace metals are often altered in the process of development of malignancy but there is a considerable controversy over their role in human cancer, probably because of differences in age, sex or diet, or difficulties in analysing trace elements accurately [11, 21].

Some authors suggest that an imbalance in the level of studied elements in cancer tissues may be due to the changed cellular metabolism in the cancer process $[18,22]$. It means that a changed status of elements in the cancer tissues may not be a cause of the disease but, in fact, a result of the disease itself.

On the other hand, some published reports reveal that laryngeal cancers sometimes have an occupational aetiology. Several authors have reported an increased risk for laryngeal cancer among workers in a nickel refinery in Norway [23], painters in Sweden [24] and in the US workers in the railroad and lumber industry, sheet metal workers, grinding wheel operators and automobile mechanics [25].

In a case-control study of all new cases of laryngeal cancer in Denmark from 1980 to 1982 it was found that exposure to nickel increases the incidence rate of laryngeal cancer [26]. The results of our studies revealed a significantly higher concentration of the studied elements in the tumours in patients from rural areas than in the tumours in patients from urban areas; therefore it may suggest a strong relationship between the content of these metals in the tumours and the working and living environment. Apart from that, the significantly higher concentration of nickel found in healthy tissue in patients from rural areas in comparison with the content of this metal in healthy tissue in patients from urban areas points to an urgent need for further studies that will take into account the environmental and occupational risk factors for studied patients in order to explain the results of our studies.

In conclusion, we agree with other authors that the imbalance in the level of nickel, cadmium and cobalt in laryngeal cancer may be due to a changed cellular metabolism in the cancer process. However, the results of our study reveal the significant differences in the concentration of these metals between patients from urban and rural areas, which suggests that this fact may be related to environmental or occupational factors and therefore it requires further study.

\section{References}

1. Arita A, Costa M. Epigenetic in metal carcinogenesis: nickel, arsenic, chromium and cadmium. Metallomics 2009; 1: 222-8.

2. Chen HB, Ke QD, Kluz T, Yan Y, Costa M. Nickel ions increase histone $\mathrm{H} 3$ lysine 9 dimethylation and induce transgene silencing. Mol Cell Biol 2006; 26: 3728-37.

3. Takiguchi M, Achanzar WE, Qu W, Li GY, Waalkes MP. Effects of cadmium on DNA-(cytosine-5) methyltransferase activity and DNA methylation status during cadmium-induced cellular transformation. Exp Cell Res 2003; 286: 355-65.

4. Gault N, Sandre C, Poncy JL, Moulin C, Lefaix JL, Breson C. Cobalt toxicity: chemical and radiological combined effects on HaCaT keratinocyte cell line. Toxicol. In Vitro 2010; 24: 92-8.

5. Sobin LH, Wittekind CH. UICC-TNM classification of malignant tumours. 5th ed. Wiley-Liss, New York 1997.

6. Agency for Toxic Substances and Diseases Registry. Toxicological Profile for cadmium. Atlanta, GA, US Department of Health and Human Services, Public Health Service 1999.

7. Verougstraete V, Lison D, Hotz P. Cadmium, lung and prostate cancer: a systematic revive of recent epidemiological data. J Toxicol Environ Health B Crit Rev 2003; 6: 227-55.

8. Ades AE, Kazantzis $G$. Lung cancer in a non-ferrous smelter: the role of cadmium. $\mathrm{Br} J$ Ind Med 1988; 45: 435-42.

9. Elinder CG, Kjellstrom T, Hogstedt C, Anderson K, Spang G. Cancer mortality of cadmium workers. Br I Ind Med 1985; 42: 651-5.

10. Pesch B, Haerting J, Rant U, Klimpel A, Oelschlagel B, Schill W. Occupational risk factor for renal cell carcinoma: agent-specific results from a case-control study in Germany. MURC Study Group. Multicenter Urothelial and Renal Cancer study. Int J Epidemiol 2000; 29: 1014-24.

11. Sorahan T, Esman NA. Lung cancer mortality in UK nickelcadmium battery workers, 1947-2000. Ocup Environ Med 2004; 61: 108-16.

12 Arisawa K, Nakano A, Saito H, et al. Mortality and cancer incidence among a population previously exposed to environmental cadmium. Int Arch Occup Environ Health 2001; 74: 255-62.

13. Nawrot T, Plusquin M, Hogervorst J, et al. Environmental exposure to cadmium and risk of cancer: a prospective population-based study. Lancet Oncol 2006; 7: 119-26. 
14. Doll R, Mathews JD, Morgan LG. Cancers of the lung and nasal sinuses in nickel workers. Br J Med 1977; 34: 102-5.

15. Sunderman FW Jr, Maenza RM, Hopfer SM, Mitchell JM, Allpass PR, Damajanov I. Induction of local cancer in rats by intrarenal injection of nickel subsulfate. J Environ Pathol Toxicol 1979; 2: 1511-27.

16. Bucher JR, Hailey JR, Roycroft JR, et al. Inhalation toxicity and carcinogenicity studies of cobalt sulfate. Toxicol Sci 1999; 49: 56-67.

17. International Agency for Research on Cancer (IARC). Monographs on the Evaluation of Carcinogenic Risk to Humans. Chlorinated Drinking-water; Chlorination Byproducts; Some Other Halogenated Compounds; Cobalt and Cobalt Compounds. 52, IARC, Lyon, France 1991.

18. Rostowska-Nadolska B, Pospiech L. The content of trace elements in the tissue of squamous cell carcinoma of the larynx. Otolaryng Pol 1999; 53: 267-70.

19. Pilch J, Łaskawiec J, Lisiewicz J, Gierek T. Qualitative determination of chemical compounds In the tissue of laryngeal cancer by $\mathrm{x}$-ray microanalysis. Otolaryngol Pol 1992; 46: 543-52.

20. Collecchi P, Esposito M, Brera S, Mora E, Mazzucotelli A Oddone $M$. The distribution of arsenic and cobalt in patients with laryngeal carcinoma. J Appl Toxicol 1986; 6: 287-9.

21. Ward NI, Stephens R, Ryan DE. Comparison of three analytical methods for the determination of trace elements in whole blood. Anal Chim Acta 1979; 110: 9-19.

22. Durak I, Kavutcu M, Canbolat O, Isik AU, Akyol O. Concentration of some major and minor elements In larynx tissues with and without cancer. BioMetals 1994; 7: 45-8.

23. Pedersen E. Cancer of respiratory organs among workers at a nickel refinery in Norway. Int J Cancer 1973; 12: 32-41.

24. Englund A. Cancer incidence among painters and some allied trades. J Toxicol Environ Health 1980; 6: 1267-73.

25. Flanders WD, Rothman KI. Occupational risk for laryngeal cancer. Am J Public Health 1982; 72: 369-72.

26. Olsen J, Sabroe S. Occupational cause of laryngeal cancer. J Epidemiol Community Health 1984; 38: 117-21. 